検討した。いずれも最新の技術を用いた新しい知見を 呈示し，活発な討論が行われたが，今後のこの方面の

\title{
(1) 鼻粘膜非特異的過敏性の臨床的実験的検討
}

\author{
鵜 䎤 幸太郎（三重大）
}

気道過敏性は下気道において現在までに多方面から 検討されており，気道上皮の障害と密接な関連がある と考えられている。今回上気道における過敏性に関し 臨床的実験的に検討しこれらを鼻粘膜上皮の病態と対 比させ興味ある知見が得られたので報告した。

鼻における過敏性の測定は七トではヒスタミンの 10 倍段階希积液を濃度のうすい方から順に一定間隔を置 いて点鼻し，くしゃみ発作または水性鼻漏が出現する までの濃度を闒値とした。 またモルモットにおいては 片側外鼻孔にヒスタミン 2 倍希釈液を濃度のうすい方 から順に点鼻し，鼻閉や鼻汁過多による「ズルズル」 音が聴取されるまでの濃度を閾値とした。

まず臨床的には60歳以上の高齢者群と39歳以下の若 年者群に分けて検討した. 正常対照群の39歳以下と60 歳以上との間に差がみとめられ，加齢により過敏性閥 值は上昇する傾向にあることがわかった３9歳以下の 群においては鼻アレルギーと慢性副鼻控炎について検 討した．鼻アレルギーでは対照群に比べ有意に低下し ていたが，副鼻腔炎のそれは対照との間に差がなかっ た。一方60歳以上の群では慢性副鼻腔炎, 鼻アレルギ 一, 喉摘者について検討した。鼻アレルギーは対昭に 比べ有意に低下していたが副鼻腔炎，喉摘者のそれは 対照との間に有意差はみられなかった。次にモルモッ 卜を用いて実験的に種々のモデルを作り過敏性闘值を 測定した。卵白アルプミンを用いて腹腔内感作および 経気道感作を行った鼻アレルギーモデルでは対照に比 ベ有意に閾值が低下した。しかしアゼラスチンを 3 週 間経口投与した群では闌値の低下は抑制された。正常 モルモットにパラインフルエンザウイルスを用いて感 染させた時, 接種 2 日目, 4 日目の過敏性はいずれも 対照に比べ闇值の上昇がみとめられ，この傾向は亜硫 酸ガス $1 \mathrm{ppm} て ゙ 30$ 日間あるいは $3,8,26 \mathrm{ppm} て ゙ 9$ 日間
曝露した時にも同様の結果が得られた。

次に鼻粘膜上皮の組織学的所見を過敏性と対比させ て検討した。鼻アレルギー症例下鼻甲介粘膜の光頙像 では上皮内および上皮下に好酸球浸潤を多数認めた が，上皮細胞や織毛の脱落は認めなかった。過敏性閾 值は鼻アレルギー，喘息いずれにおいても低下してい るが上皮障害は下気道において著しいのに対し上気道 ではこれがほとんどみとめられなかったことから過敏 性を上皮障害と結びつけるのに矛盾している。一方慢 性副鼻腔炎症例の光影像では上皮障害, 上皮内の好中 球浸潤が著明であった。しかし先に述べたように過敏 性は対照と比べ差がなかったことから上皮障害や好中 球浸潤で下気道に過敏性が方進するという報告とは矛 盾する。 ヒト鼻アレルギー下鼻甲介粘膜の TEM 像で は tight junctionの幅は150〜250^であり対照群と差 はなかった. しかし HRP を鼻内噴霧しその10分後に 採取した下鼻甲介粘膜の TEM 像では刘照群では細胞 間隙における HRP 反応物質がみとめられなかったの に対し，鼻アレルギーでは細胞間隙に高頻度に取り込 まれていた.このことは tight junctionの形態的変化 というよりも機能的な変化により透過性が六進したも のと考えられた。次に鼻アレルギーモルモットについ て同様の検討を行った。非誘発時の鼻中隔粘膜光顕像 では多数の好酸球が上皮内に認めたが上皮細胞の障害 はみられなかった。しかし屠殺30分前に鼻腔内に HRP を投与した場合対照では HRP 反応物質が紐胞 間隙に認められるのに対し鼻アレルギーモデルではこ れらの反応物質が細胞全体に取り込まれていた。

以上臨床的実験的結果から鼻粘膜の過敏性は上皮の 部分的な変性あるい注細胞間隙における透過性光進が 原因の1つになるのではないかと考元られた。

（2）炎症細胞と組織細胞との相互作用

\section{福田勝則・松崎 勉・伊東一則・今村洋子（鹿大）}

気道粘膜には, 粘膜組織を構成する粘膜上皮細胞, 結合織細胞, 血管細胞を基本に, 各種病態に応じてマ クロファージ, 多形核白血球, 肥満細胞, リンパ球, 形質細胞等の免疫担当細胞が観察される. 近年, 細胞 培養の技術の進歩に伴い, 細胞レベルでの病態解明が なされており, 組織細胞と免疫細胞との相互作用が,
炎症を中心とする病態の形成に重要な役割を担ってい ることが判明してきた. 我々は, 鼻粘膜由来の培養細 胞を用いて, 鼻粘膜病態の解明を進めている。 その中 で，鼻茸より explant 法にて培養した線維芽細胞のコ ラダナーゼ産生を促進させる因子が慢性副鼻腔炎患者 の鼻汁中に存在することを見いだした。線維芽細胞培 